\title{
The Jambi Provincial Government Policy Of Merangin District Concerning In Suku Anak Dalam (SAD)
}

\author{
Riswanto Bakhtiar ${ }^{1}$, Henny Puspita Sari ${ }^{2}$, Zumiarti $^{3}$, Annisa Fitri ${ }^{4}$, Sayid Anshar ${ }^{5}$ \\ $\left\{\right.$ aris.pkbkrc@gmail.com ${ }^{1}$, hpssp.henny@gmail.com ${ }^{2}$, \\ theartzumi@gmail.com ${ }^{3}$, annisafitri196@yahoo.com ${ }^{4}$, ancasaid14@gmail.com ${ }^{5}$ \}
}

Faculty of Social and Political Sciences, Ekasakti University, Padang ${ }^{1,3,4,5}$ Institute for Research and Community Service, Ekasakti University, Padang ${ }^{2}$

\begin{abstract}
The policy of the provincial government of Jambi, Merangin district regarding ethnicity of children is guided by Law no. 6 of 2014 concerning Villages; Permendagri No. 52 of 2014 concerning Guidelines for the Recognition and Protection of Indigenous and Tribal Peoples; and Decree of the Minister of Social Affairs Number 187 / Huk / 2018 concerning Stipulation of Locations for Social Empowerment of Remote Indigenous Communities in 2019. Based on this regulation, the Merangin district government has issued a program specifically for Suku Anak Dalam (SAD), namely the Remote Community Welfare Development Program (PKSMT). Where there are 5 programs that have been targeted, but of the five PKSMT programs that are running there are only 4 programs namely: (a) Settlements, (b) Smart Houses, (c) Empowerment, (d) Health.
\end{abstract}

Keywords: Policy, Jambi Province, Merangin, Suku Anak Dalam, PKSMT

\section{Introduction}

Suku Anak Dalam (SAD) is one of the tribes in Indonesia that still lives traditionally in forest areas [1]. According to Mailinar \& Nurdin (2013) there are several other terms attached to SAD such as Remote Indigenous Communities, Kubu People, and Rimba People. In genealogy, suku anak dalam (SAD) in Jambi province comes from three breeds, namely: first, descendants from South Sumatra who generally live in Batanghari district. Second, the descendants of Minang Kabau who generally live in Bungo district, Tebo district, parts of Mersam and Batanghari districts. Third, the descendants of the original ethnic Jambi people who live in the Air Hitam area of the Sarolangun district.

The SAD / Orang Rimba community calls the forests in Jambi Province a wandering area: where they interact with nature, give and receive and support one another. To fulfill their daily needs, the Orang Rimba are engaged in hunting, fishing, looking for honey, and tapping rubber for sale [3]. The SAD community is part of an isolated community group in the Jambi Province with a total population of 200,000 [4]. Suku Anak Dalam (SAD) is spread over 8 districts in Jambi Province respectively in Sarolangun Regency, Merangin Regency, Muara Bungo Regency, Muara Tebo Regency, Batanghari Regency, Muara Jambi Regency, Muara Tanjung Jabung Barat Regency and East Tanjung Jabung Regency. They live isolated and left behind.

Geographical remoteness has consequences for the limited access for remote indigenous communities to various social, economic and services in order to meet their basic needs with 
geographic remoteness, this community experiences limitations to reach other areas to get their needs met. As citizens, SAD is also entitled to the same justice as society in general. Therefore, the principle of structural justice in life together with all people in the world must receive attention, where the State (Government) is responsible for ensuring that every citizen is treated equally in the eyes of the law and has access to justice [5].

The central and regional governments make policies one of them through the Remote Indigenous Community Empowerment Program (PKAT) [6]. The government makes settlements, builds houses, introduces agricultural methods, formal education, health facilities, religion and interactions with other communities. The government changed the socio-culture of SAD from living a nomadic life, hunting and gathering to settling and farming. Along with the PKAT program, the government granted plantation and timber utilization licenses to plantation companies and forestry companies and established transmigration settlements adjacent to the forest areas inhabited by SAD.

In addition there is recognition and protection of the rights and obligations of indigenous peoples as part of Indonesian citizens in Law No. 6 of 2014 concerning Villages. Apart from villages, Law 6/2014 also recognizes the existence of Traditional Villages. The regional government can arrange the customary law community unit and determine it to become a Customary Village through a regional regulation. Provided that the three criteria for Traditional Village are fulfilled, namely that the customary law community unit and its traditional rights are still alive, and in accordance with community development and in line with the principles of the Unitary State of the Republic of Indonesia. In addition, the issuance of Permendagri No. 52/2014 concerning Guidelines for the Recognition and Protection of Customary Law Communities, can be used as a reference for regional heads to provide recognition and protection for indigenous peoples.

The implementation of a policy in order to be effective must be with the support of various parties, both from human and other resources, with concern for the empowerment of Remote Indigenous Communities that have been made, empowering Isolated Indigenous Communities has a good impact and runs as it should.

\section{Methodology}

The research method used in this research is the type of field research. The research approach is a qualitative approach with the type of data used primary data and secondary data, data sources obtained from the Office of the Regent of Merangin Regency, the Office of Social Affairs, Women's Empowerment and Child Protection in Merangin Regency, mass media, and documentation. Data collection is done by interview, and document search.

\section{Finding and Discussion}

\subsection{Overview of Merangin Regency}

Merangin Regency is one of the districts in Jambi Province. Merangin Regency was formed from the division of Sarolangun Bangko Regency into Merangin Regency and Sarolangun Regency. Merangin Regency was formed based on Law no. 54 of 1999 dated October 4, 1999 concerning the formation of Sarolangun Regency, Tebo Regency, Muaro Jambi Regency and Tanjung Jabung Timur Regency. In this case Merangin Regency as the main 
district remains with the government capital in Bangko City, which was also the capital of Sarolangun Bangko Regency before its division. Merangin Regency currently consists of 24 Districts, 205 Villages and 10 Village offices [7].

Table 1. List of districts and villages in Merangin Regency.

\begin{tabular}{clcc}
\hline No. & District Name & $\begin{array}{c}\text { Total Of } \\
\text { Villages }\end{array}$ & $\begin{array}{c}\text { Total Of Sub- } \\
\text { District }\end{array}$ \\
\hline 1. & Jangkat & 11 & \\
2. & Jangkat Timur & 14 & \\
3. & Muara Siau & 17 & \\
4. & Lembah Masurai & 15 & \\
5. & Tiang Pungpung & 6 & \\
6. & Pamenang & 13 & \\
7. & Pamenang Barat & 8 & \\
8. & Renah Pamenang & 4 & \\
9. & Pamenang Selatan & 4 & \\
10. & Bangko & 4 & \\
11. & Bangko Barat & 6 & \\
12. & Nalo Tantan & 7 & \\
13. & Batang Masumai & 10 & \\
14. & Sungai Manau & 10 & \\
15. & Renah Pembarap & 12 & \\
16. & Pangkalan Jambu & 8 & \\
17. & Tabir & 6 & \\
18. & Tabir Ulu & 6 & \\
19. & Tabir Selatan & 8 & \\
20. & Tabir Ilir & 7 & \\
21. & Tabir Timur & 4 & \\
22. & Tabir Lintas & 5 & \\
23. & Margo Tabir & 6 & \\
24. & Tabir Barat & 14 & \\
\hline & & Data source: Merangin Regency, 2020 & \\
& & &
\end{tabular}

\subsection{Merangin Regency Policy}

Through structured development planning, it can identify various problems that will be faced in people's lives so that Merangin districts can formulate social development programs through regulations issued by the central government, which are guided by: 


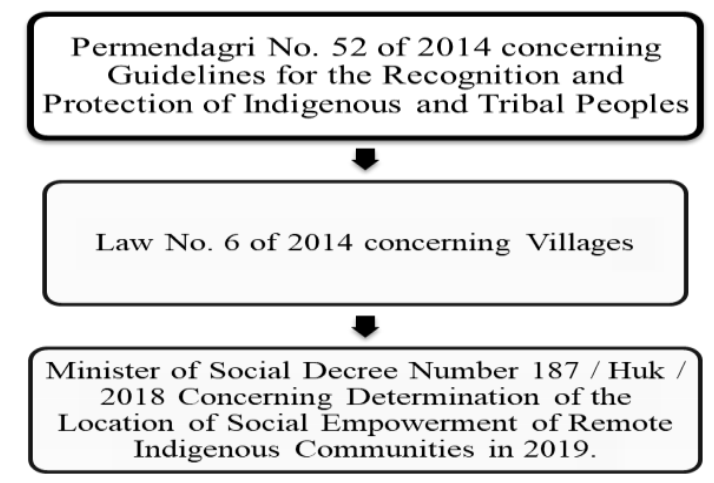

Fig. 1. Kebijakan Kabupaten Merangin.

Based on this regulation, the Merangin district government has issued a program specifically for the Inner Child Tribe (SAD), namely the Remote Community Welfare Development Program (PKSMT). The PKSMT program is a coaching effort given to socially vulnerable groups due to backwardness and alienation, with the aim of creating social conditions that are suitable for modern people's lives and participating in development.

PKSMT activities are always oriented towards isolated communities and are located in rural areas who experience underdeveloped communication with other communities. In accordance with its objectives, PKSMT helps to alleviate SAD from being alienated by outsiders and being left behind in various aspects. PKSMT can strengthen SAD in order to have a stable life in accordance with standard norms adhered to by the Indonesian people such as embracing an official religion recognized by the government and living in villages and adapting to the social environment.

The PKMST program is part of the program in the Social Service and is handled by KAT (Remote Indigenous Communities) under the Head of Social Welfare Empowerment. KAT acts as a forum for Suku Anak Dalam (SAD) and facilitators who will meet their needs and play a role in shaping and training SAD communities who are still underdeveloped. In implementing the PKSMT KAT program in partnership with the Pundi Sumatera NGO. The Pundi Sumatera NGO is a facilitator in implementing the PKSMT program.

The existing program has been designed to suit the life patterns of the Anak Dalam Tribe. Where there are 5 programs that have been targeted, namely: (a) Settlements, (b) Smart Houses, (c) Empowerment, (d) Health. Of the five PKSMT program that runs only 4 programs:

a. Settlements

Previous SAD settlements were not semi-permanent, but rather like tents using tarpaulin. This program is the first program implemented, where KAT implemented SAD settlements in September 2017. The settlements built under the PKSMT program did not involve SAD or surrounding communities, but were submitted to KAT. The new SAD settlement is \pm 500 $\mathrm{m}$ from the local community settlement. SAD settlements are built with a type of settlement in a new place or exsitu construction, meaning that it is built in a semi-permanent new place.

b. Smart Houses

Smart houses are a means of providing education to SAD. After completing the temporary housing program for SAD in September 2017 KAT built a smart house located in the SAD residential area. KAT builds smart houses in residential areas because it will make it easy to reach by SAD. Activities at the smart home are carried out to increase knowledge for SAD 
children that are not obtained in formal schools. Activities that they do in the smart home they routinely do in once a week meeting on Saturdays and members of the NGO Pundi Sumatra as a teacher in the smart home. Activities at the smart home do not only provide education but also socialization such as health education and providing insight into livelihoods apart from hunting and funerals.

c. Empowerment

Empowerment is an effort to generate community resources, opportunities, knowledge and skills to increase capacity in determining the future.[8] In man he has the potential and power in himself. Empowerment is always done continuously to improve the ability and independence in improving their standard of living. The form of empowerment programs provided to the Anak Dalam Tribe in Merangin Regency is such as raising animals and farming. The empowerment program began to be implemented in February 2018 in the new settlement.

d. Health

Health is the most important part that must be owned by every human soul. The government has made it easy for SAD to get health services. The health program provided for SAD is in the form of Health Insurance (JamKes). The provision of JamKes makes it easy for SAD because they can get free treatment in all areas of Meragin Regency. In addition to providing the Jamkes LSM Pundi Sumatera and KAT program during the guidance process in August 2017, SAD was also directed to start health from small things, namely from the SAD lifestyle itself. By getting used to a healthy lifestyle such as bathing 2 times a day, will prevent them from getting sick. Especially with the lives of those who are still hunting in the forest as a place to make a living. In addition, the provision of health education is facilitated by health department clinic.

The PKSMT program for SAD, which is implemented by the government, is part of a structure that has members and contains programs that have their respective functions in order to achieve shared goals. So that the aspects of life result in the atmosphere of each community being in a very intensively influencing relationship [5]. Where the program implemented by the government for Suku Anak Dalam (SAD) to help alleviate isolated communities from being left behind and underdeveloped in various fields and can adapt to the social environment and live on an equal footing with other more advanced societies and eventually become independent societies.

This functional structure theory has four functions that are needed in a system commonly called the AGIL scheme. The function of the AGIL scheme is a group of activities directed to meet one or several system requirements, that is:

1) Adaption is a points to the necessity for social systems to deal with their environment. The implementation of the PKSMT program carried out by the Remote Indigenous Community (KAT) under the authority of the Social Service for a group of Suku Anak Dalam according to their nomadic (moving) life.

2) Goal Attainment, is a requirement that the actions of a group of people are directed towards its goals, and to achieve the goals of the PKSMT KAT program, run this PKSMT program assisted by the Pundi Sumatera NGO.

3) Integration equirements related to internalization between members in the social system, by implementing the PKSMT program, have carried out a good integration of integration between SAD itself and local communities where it is seen when they live in the same area, making them mingle and helping each other when they need assistance. this was when SAD was getting married to a family, the local community worked together to help the marriage process. On the other hand, SAD is already open to the outside community. 
4) Latency a system must complement, maintain, and improve either individual or cultural motivation which creates and sustains motivation. The maintenance of values and norms has an important role in community life, where SAD facilitators help in maintaining the values and norms that exist in SAD communities.

\section{Conclusion}

The policy of the provincial government of Jambi, Merangin district regarding ethnicity of children is guided by Law no. 6 of 2014 concerning Villages; Permendagri No. 52 of 2014 concerning Guidelines for the Recognition and Protection of Indigenous and Tribal Peoples; and Decree of the Minister of Social Affairs Number 187 / Huk / 2018 concerning Stipulation of Locations for Social Empowerment of Remote Indigenous Communities in 2019. Based on this regulation, the Merangin district government has issued a program specifically for Suku Anak Dalam (SAD), namely the Remote Community Welfare Development Program (PKSMT) . Where there are 5 programs that have been targeted, but of the five PKSMT programs that are running there are only 4 programs namely: (a) Settlements, (b) Smart Houses, (c) Empowerment, (d) Health.

Acknowledgments. The Research Team thanks to the Directorate of Research and Community Service in the Field of Strengthening Research and Development of the Ministry of Research and Technology / National Research and Innovation Agency for helping to fund the implementation of this research in accordance with the Research Implementation Contract with LLDIKTI Region X Number: 077 / LL10 / PG / 2020

\section{References}

[1] Harnov, E. Amzu, and R. Soekmadi, "Konservasi Hutan Belajar Dari Nilai-Nilai Etik Dan Tradisi Bejernang Suku Anak Dalam Di Taman Nasional Bukit Duabelas, Provinsi Jambi," Risal. Kebijak. Pertan. DAN Lingkung., vol. 3, no. 1, pp. 24-38, 2016.

[2] Mailinar and B. Nurdin, "Kehidupan Keagamaan Suku Anak Dalam di Dusun Senami III Desa Jebak Kabupaten Batanghari Jambi,” Kontekstualita, vol. 28, no. 2, pp. 141-157, 2013.

[3] I. Fahmi, Analisis Investasi Dalam Perspektif Ekonomi dan Politik. Bandung: Refika Aditama, 2006.

[4] Wandi, "Konflik Sosial Suku Anak Dalam (Orang Rimba) di Provinsi Jambi," Simulacra, vol. 2, no. 2, pp. 195-207, 2019.

[5] Juladdin, "Akses (Justice) Mendapatkan Keadilan Dalam Konstitusi Indonesia," UNES LAW Rev., vol. 2, no. 2, pp. 137-143, 2019.

[6] E. Kurniawan, A. Ratna Kusuma, and A. Idris, "Implementasi Kebijakan Program Pemberdayaan Komunitas Adat Terpencil (KAT) Dalam Menanggulangi Kemiskinan Di Lokasi Sekulit Desa Munggu Kecamatan Longkali Kabupaten Paser,” J. Adm. Reform, vol. 3, no. 3, pp. 374-385, 2015.

[7] BPS, kabupaten merangin dalam angka 2020. Jambi: BPS Kabupaten Merangin, 2020.

[8] Z. Rohmad, Sosiologi Pembangunan. Yogyakarta: Penerbit ombak, 2016. 